\title{
Ru-Porphyrin Protein Scaffolds for Sensing 02
}

\section{Citation}

Winter, Michael B., Emily J. McLaurin, Steven Y. Reece, Charles Olea, Daniel G. Nocera, and Michael A. Marletta. 2010. "Ru-Porphyrin Protein Scaffolds for Sensing 02." Journal of the American Chemical Society 132 (16) (April 28): 5582-5583. doi:10.1021/ja101527r.

\section{Published Version}

doi:10.1021/ja101527r

\section{Permanent link}

http://nrs.harvard.edu/urn-3:HUL.InstRepos:33464241

\section{Terms of Use}

This article was downloaded from Harvard University's DASH repository, and is made available under the terms and conditions applicable to Open Access Policy Articles, as set forth at http:// nrs.harvard.edu/urn-3:HUL.InstRepos:dash.current.terms-of-use\#OAP

\section{Share Your Story}

The Harvard community has made this article openly available.

Please share how this access benefits you. Submit a story.

Accessibility 


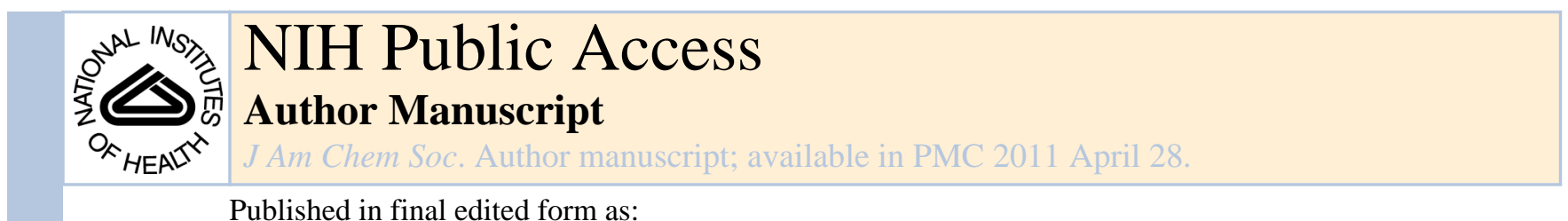

J Am Chem Soc. 2010 April 28; 132(16): 5582-5583. doi:10.1021/ja101527r.

\title{
Ru-Porphyrin Protein Scaffolds for Sensing $\mathrm{O}_{2}$
}

\author{
Michael B. Winter $\dagger$, Emily J. McLaurin $\ddagger$, Steven Y. Reece ${ } \S$, Charles Olea Jr. $\dagger^{,}$, Daniel G. \\ Nocera $\ddagger$, and Michael A. Marletta ${ }^{\dagger}$ \\ tDepartment of Chemistry, QB3 Institute, and Division of Physical Biosciences, Lawrence \\ Berkeley National Laboratory, University of California, Berkeley, California 94720-3220 USA; \\ Department of Molecular and Cell Biology, QB3 Institute, and Division of Physical Biosciences, \\ Lawrence Berkeley National Laboratory, University of California, Berkeley, California 94720-3220 \\ USA
}

‡Department of Chemistry, 77 Massachusetts Avenue, Massachusetts Institute of Technology, Cambridge, Massachusetts 02139-4307 USA

\section{Abstract}
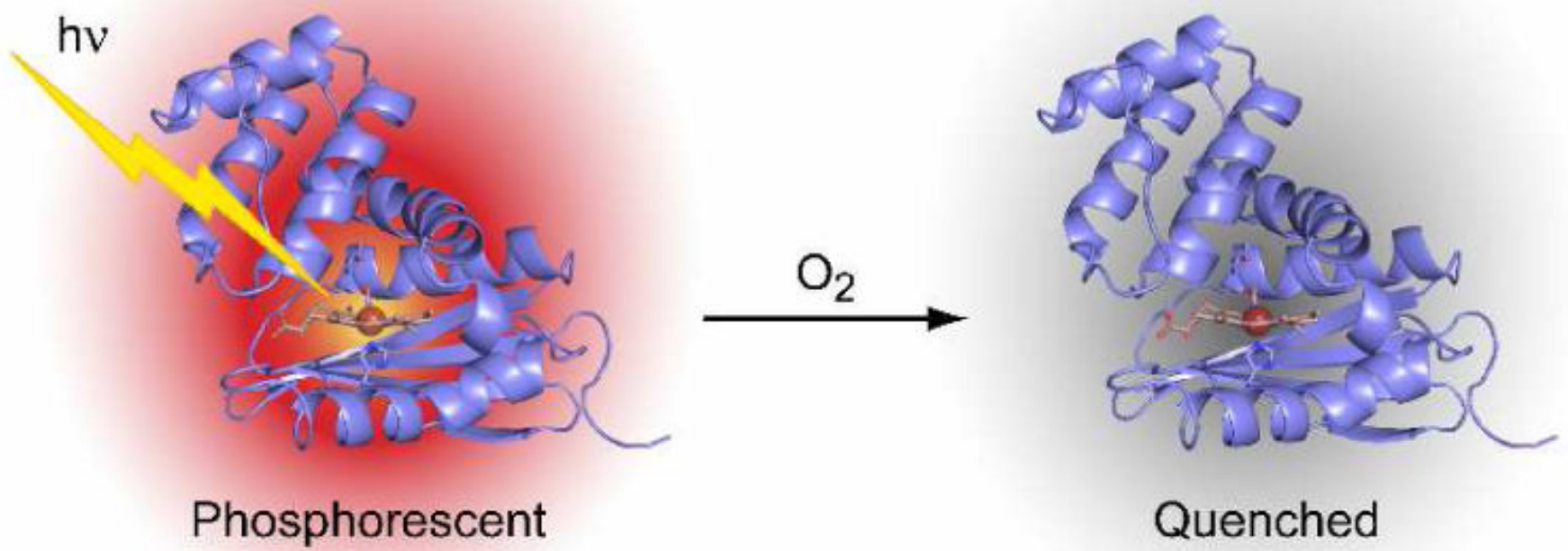

Quenched

\begin{abstract}
Hemoprotein-based scaffolds containing phosphorescent ruthenium(II) CO mesoporphyrin IX (RuMP) are reported here for oxygen $\left(\mathrm{O}_{2}\right)$ sensing in biological contexts. RuMP was incorporated into the protein scaffolds during protein expression utilizing a novel method that we have described previously. A high-resolution $(2.00 \AA)$ crystal structure revealed that the unnatural porphyrin binds to the proteins in a manner similar to the native heme and does not perturb the protein fold. The protein scaffolds were found to provide unique coordination environments for RuMP and modulate the porphyrin emission properties. Emission lifetime measurements
\end{abstract}

marletta@berkeley.edu

$\S_{\text {Current Address: Sun Catalytix, Cambridge, Massachusetts }}$

Supporting Information Available: Synthetic details, porphyrin stochiometry, further photophysical characterization of the RuMP proteins, structural alignments, and x-ray diffraction data. 
demonstrate a linear $\mathrm{O}_{2}$ response within the physiological range and precision comparable to commercial $\mathrm{O}_{2}$ sensors. The RuMP proteins are robust, readily-modifiable platforms and display promising $\mathrm{O}_{2}$ sensing properties for future in vivo applications.

Proteins that natively bind heme are under-utilized scaffolds for porphyrin-based tools in biology. ${ }^{1,2}$ Porphyrins have broad applications, ranging from dyes in solar cells ${ }^{3}$ to sensitizers for radiotherapy ${ }^{4}$ to frameworks for catalysis. ${ }^{5}$ Traditional methods for unnatural porphyrin incorporation into hemoproteins have limited their utility as biological tools. Harsh, denaturing conditions are typically required to remove native heme from proteins, ${ }^{6,7}$ dramatically decreasing the number of viable protein constructs. We recently reported a novel method for incorporation of unnatural porphyrins into hemoproteins during protein expression. ${ }^{8}$ Here we demonstrate the versatility of this expression-based method through the development of protein-based sensors, in which the native heme cofactor of different hemoprotein scaffolds has been substituted with an unnatural porphyrin for oxygen $\left(\mathrm{O}_{2}\right)$ sensing within biological contexts.

$\mathrm{O}_{2}$ is a key metabolic indicator for profiling the physiology of tissues and cells. ${ }^{9}$ Quenching of small molecule luminescence by $\mathrm{O}_{2}$ is a simple, non-invasive method for imaging in vivo $\mathrm{O}_{2}$ levels. ${ }^{10}$ However, the utility of small molecules for this application is hampered by lack of targetable delivery, non-specific binding, self-aggregation, and limitations in photophysical properties. ${ }^{11,12}$ Incorporation of luminescent porphyrins into hemoprotein scaffolds provides a novel platform to address these issues.

Ruthenium(II) CO mesoporphyrin IX (RuMP) (Figure S1) is an ideal cofactor for proteinbased sensors because it exhibits $\mathrm{O}_{2}$-senstive phosphorescence 13 and presents a proximal axial ligation site ${ }^{14}$ to facilitate binding to the protein scaffold. Myoglobin $(\mathrm{Mb})$ and the $\mathrm{H}$ NOX (Heme Nitric oxide / OXygen binding) domain from the thermophilic bacterium Thermoanaerobacter tengcongensis (Tt $\mathrm{H}-\mathrm{NOX})$ are robust proteins for RuMP sensors, as they can be readily modified with genetically-encoded affinity tags and site-directed mutagenesis. ${ }^{1,15}$ In addition, $T t \mathrm{H}-\mathrm{NOX}$ is stable under extreme temperatures $\left(>70{ }^{\circ} \mathrm{C}\right) .{ }^{15}$

Experimental details for preparation and characterization of RuMP-substituted $\mathrm{Mb}(\mathrm{Ru} \mathrm{Mb})$ and $T t$ H-NOX (Ru $T t$ H-NOX) are described in Supporting Information. Briefly, RuMP was synthesized in a manner similar to published methods ${ }^{14}$ and incorporated into $\mathrm{Mb}$ and $T t \mathrm{H}$ NOX during anaerobic protein expression. The RuMP-substituted proteins were isolated containing a stochiometric amount of porphyrin (Table S1). Indeed, further evaluation of the stability of Ru $T t \mathrm{H}-\mathrm{NOX}$ indicated no detectible porphyrin loss for $>24$ hours under biological conditions (mouse plasma at $37{ }^{\circ} \mathrm{C}$, Figure S2).

Purified Ru $T t \mathrm{H}-\mathrm{NOX}$ was crystallized to verify proper porphyrin insertion and preservation of the protein fold. The high-resolution (2.00 $⿱$ ) structure of Ru Tt H-NOX (Figure 1, Table S2) is the first crystal structure of a Ru porphyrin bound to a protein and demonstrates that the unnatural porphyrin maintains key contacts with surrounding heme pocket residues. These contacts include coordination of the proximal histidine to Ru and hydrogen bonding between the distal porphyrin ligand and a tyrosine residue (Figure 1, Figure S3). In fact, comparison of heme-bound $T t$ H-NOX with its Ru analogue indicates little perturbation of the protein fold (overall rmsd 1.3 A, Figure S4).

Steady-state and time-resolved spectroscopies were employed to examine the spectral properties of RuMP bound to the protein scaffolds. UV-visible spectra for Ru Tt H-NOX and $\mathrm{Ru} \mathrm{Mb}$ show similar Soret band features at $400 \mathrm{~nm}$ and $397 \mathrm{~nm}$, respectively (Figure 2, Table 1). However, the $\alpha$ band at $\sim 550 \mathrm{~nm}$ for $\mathrm{Ru} \mathrm{Mb}$ is split, as observed previously. ${ }^{14}$ Steady-state emission spectra reveal a blue-shifted emission band and decreased emission 
quantum yield for Ru Mb as compared to Ru $T t \mathrm{H}-\mathrm{NOX}$ (Table 1). Time-resolved emission spectroscopy conducted to further probe the spectral features of the porphyrin-protein complexes yielded single-exponential emission decays (following $550 \mathrm{~nm}$ laser excitation) under anaerobic conditions that vary widely between the two proteins $\left(\tau_{\mathrm{o}}=7.7 \mu\right.$ s for $\mathrm{Ru} T t$ $\mathrm{H}-\mathrm{NOX}$ vs. $37.3 \mu \mathrm{s}$ for Ru Mb, respectively). Taken together, these data indicate a substantially different conformation and/or chemical environment for RuMP in Mb and $T t$ $\mathrm{H}-\mathrm{NOX}$. Indeed, the crystal structure of Mb reveals that the heme is partially exposed to solvent, ${ }^{1}$ whereas the heme in $T t$ H-NOX is buried within the protein matrix (Figure 1).

The ability of phosphorescent molecules to sense $\mathrm{O}_{2}$ is determined by the degree of emission quenching in the presence of $\mathrm{O}_{2}$. Comparison of the steady-state emission spectra of $\mathrm{Ru} T t \mathrm{H}-\mathrm{NOX}$ and $\mathrm{Ru} \mathrm{Mb}$ measured under aerobic and anaerobic conditions reveals that $\mathrm{O}_{2}$ appreciably quenches the emission of both proteins (Figure 2). To further evaluate the highly stable $\mathrm{Ru} T t \mathrm{H}-\mathrm{NOX}$ protein as an $\mathrm{O}_{2}$ sensor, its excited state lifetime was measured at several $\mathrm{O}_{2}$ concentrations (Figure 3 ). The data were analyzed according to the SternVolmer (SV) equation for $\mathrm{O}_{2}$ quenching (Supporting Information) and yielded a bimolecular quenching constant, $k_{\mathrm{q}}$, of $1350 \mathrm{mmHg}^{-1} \mathrm{~s}^{-1}\left(8.2 \times 10^{8} \mathrm{M}^{-1} \mathrm{~s}^{-1}\right)$. In addition to intrinsic emission properties, the precision of lifetime-based $\mathrm{O}_{2}$ sensors is governed by the instrument error associated with the lifetime measurement. Taking our instrument error of $2.5 \%$ into account, $\mathrm{Ru} T t \mathrm{H}-\mathrm{NOX}$ can be used to determine $\mathrm{O}_{2}$ concentrations to within $\pm 2.5 \mathrm{mmHg}$ $(4.2 \mu \mathrm{M})$ in spite of its low quantum yield. This precision is comparable to that reported for commercial $\mathrm{O}_{2}$ sensors (Table 2) and is ideally suited for determining $\mathrm{O}_{2}$ concentrations in biology. Indeed, emission quenching was observed to be linear across the biologically relevant range of $\mathrm{O}_{2}$ concentrations (Figure 3). ${ }^{9}$

The RuMP proteins described here represent a new class of sensors for detection of dissolved $\mathrm{O}_{2}$. The sensors are readily expressed in $E$. coli, exceptionally robust, and able to detect $\mathrm{O}_{2}$ levels in the biologically relevant range. The photophysical properties may be further modulated with the choice of emissive porphyrin or through modification of the protein scaffold (e.g. via site-directed mutagenesis). In addition, the proteins may be expressed with genetically-encoded tags for targeted delivery in biology and derivatized for enhancing biocompatibility. We anticipate that this new class of sensors will prove useful for monitoring $\mathrm{O}_{2}$ levels in biological contexts. One area of particular interest for sensing $\mathrm{O}_{2}$ is in tumor microenvironments wherein detailed knowledge of local $\mathrm{O}_{2}$ concentrations is key to improving cancer diagnosis and treatment. ${ }^{9}$

\section{Supplementary Material}

Refer to Web version on PubMed Central for supplementary material.

\section{Acknowledgments}

We thank the Army Research Office (W911NF-06-1-0101) (D.G.N.) and the National Institutes of Health (R01CA126642-02) (D.G.N.) and (GM070671) (M.A.M.) for financial support. We also thank Prof. J. Kuriyan for structural analysis, Prof. C. Drennan and Prof. S. Marqusee for use of equipment, R. Tran for assistance with cloning, Dr. E. Weinert for assistance with plasma stability experiments, and Dr. A. Iavarone for mass spectrometry acquisition.

\section{References}

(1). Dou Y, Maillett DH, Eich RF, Olson JS. Biophys. Chem 2002;98:127-148. [PubMed: 12128195]

(2). Gillam EMJ. Chem. Res. Toxicol 2008;21:220-231. [PubMed: 18067267]

(3). Imahori H, Fukuzumi S. Adv. Func. Mat 2004;14:525-536.

(4). Vicente MGH. Curr. Med. Chem.: Anti-Cancer Agents 2001;1:175-194. 
(5). Chang CJ, Chng LL, Nocera DG. J. Am. Chem. Soc 2003;125:1866-1876. [PubMed: 12580614]

(6). Teale FW. Biochim. Biophys. Acta 1959;35:543. [PubMed: 13837237]

(7). Schmidt P, Schramm M, Schröder H, Stasch JP. Protein Expr. Purif 2003;31:42-46. [PubMed: 12963339]

(8). Woodward JJ, Martin NI, Marletta MA. Nat. Methods 2007;4:43-45. [PubMed: 17187078]

(9). Helmlinger G, Yuan F, Dellian M, Jain RK. Nat. Med 1997;3:177-182. [PubMed: 9018236]

(10). Vanderkooi JM, Maniara G, Green TJ, Wilson DF. J. Biol. Chem 1987;262:5476-5482. [PubMed: 3571219]

(11). Berg K, Selbo PK, Weyergang A, Dietze A, Prasmickaite L, Bonsted A, Engesaeter B , AngellPetersen E, Warloe T, Frandsen N, Høgset A. J. Microsc 2005;218:133-147. [PubMed: 15857375]

(12). Finikova OS, Lebedev AY, Aprelev A, Troxler T, Gao F, Garnacho C, Muro S, Hochstrasser RM, Vinogradov SA. Chem. Phys. Chem 2008;9:1673-1679. [PubMed: 18663708]

(13). Vanderkooi JM, Wright WW, Erecinska M. Biochim. Biophys. Acta 1994;1207:249-254. [PubMed: 8075157]

(14). Paulson DR, Addison AW, Dolphin D, James BR. J. Biol. Chem 1979;254:7002-7006. [PubMed: 572363]

(15). Boon EM, Marletta MA. J. Am. Chem. Soc 2006;128:10022-10023. [PubMed: 16881625]

(16). Oter O, Ribou AC. J. Fluoresc 2009;19:389-397. [PubMed: 18931890]

(17). Dunphy I, Vinogradov SA, Wilson DF. Anal. Biochem 2002;310:191-198. [PubMed: 12423638] 


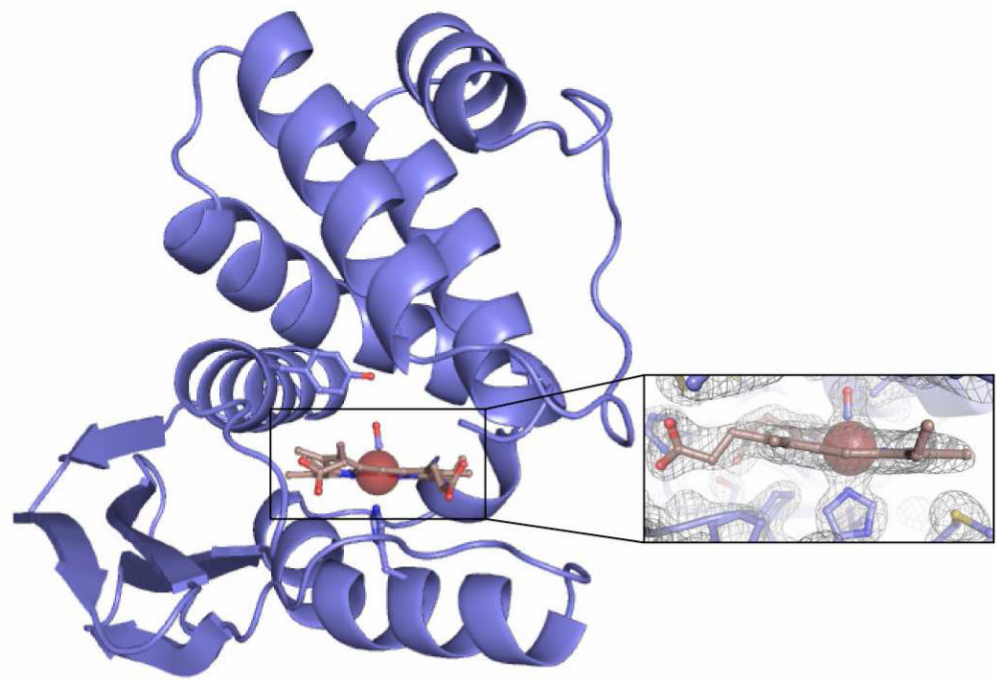

Figure 1.

Crystal structure of $T t \mathrm{H}-\mathrm{NOX}$ containing RuMP solved at $2.00 \AA$ A resolution. Inset: $2\left(\mathrm{~F}_{\mathrm{o}}-\mathrm{F}_{\mathrm{c}}\right)$ electron density map calculated by omitting RuMP and the proximal histidine side chain. 

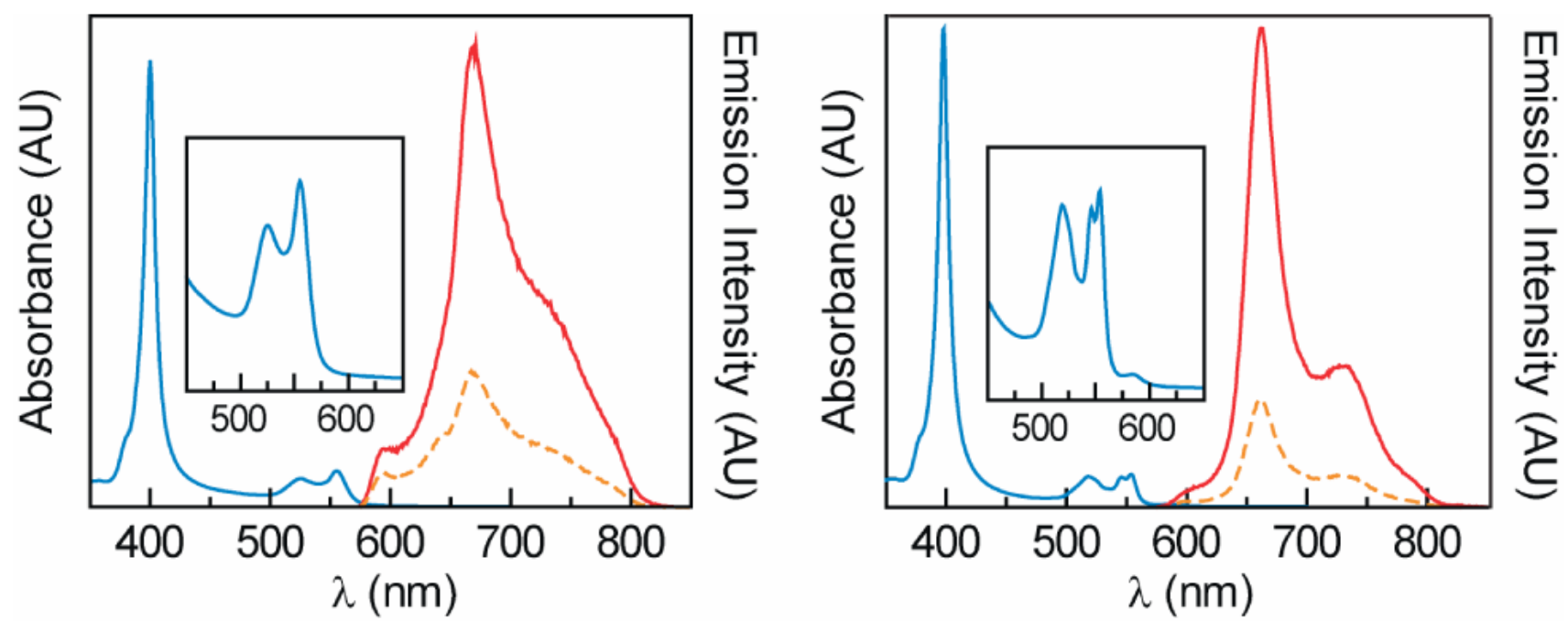

Figure 2.

Steady-state absorbance (一) and emission spectra of Ru Tt H-NOX (left) and Ru Mb (right) in aqueous $\mathrm{HEPES} / \mathrm{NaCl}$ buffer. Emission spectra were acquired following excitation at 550 $\mathrm{nm}$ in the presence (----, $256 \mu \mathrm{M})$ and absence $(-)$ of $\mathrm{O}_{2}$. 


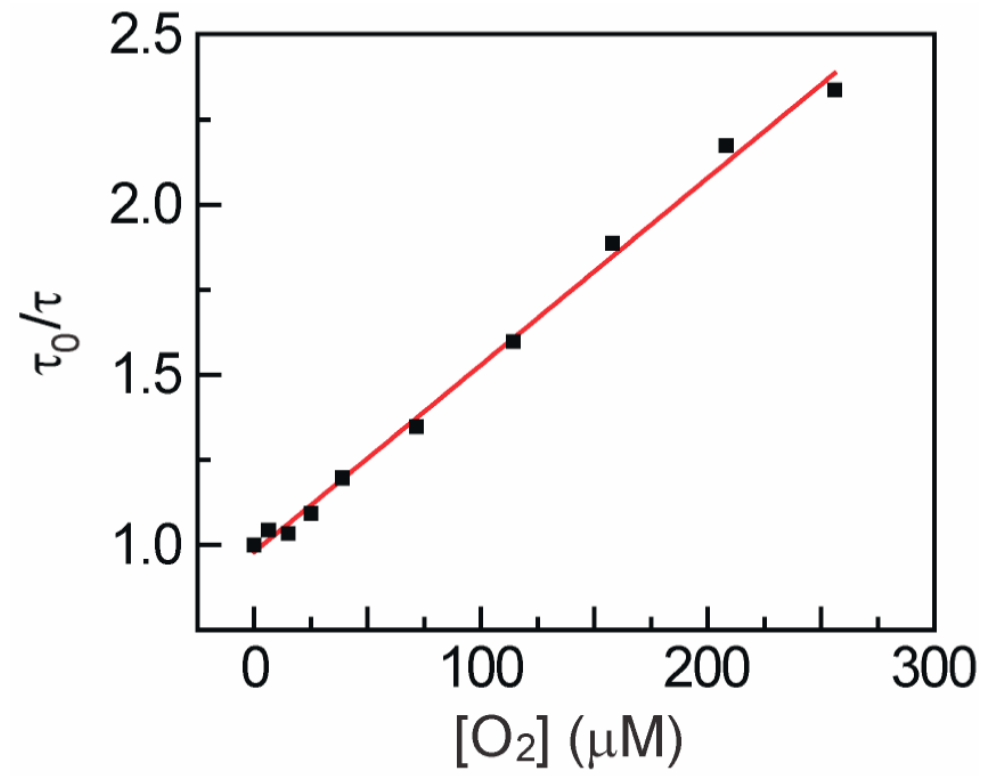

Figure 3.

Stern-Volmer plot of the excited state lifetime of $\mathrm{Ru} T t \mathrm{H}-\mathrm{NOX}$ vs. $\left[\mathrm{O}_{2}\right]$ showing linear phosphorescence quenching by $\mathrm{O}_{2}$ from 0 to $256 \mu \mathrm{M} \mathrm{O}_{2}\left(\mathrm{R}^{2}=0.9957\right)$. 


\section{Table 1}

Spectroscopic and photophysical properties of $\mathrm{Ru}$ proteins

\begin{tabular}{|c|c|c|c|c|}
\hline Ru Protein & $\lambda_{\text {abs }}(\mathbf{n m}) /(\varepsilon)$ & $\lambda_{\mathrm{em}}{ }^{a}(\mathbf{n m})$ & $\Phi_{\mathrm{em}}^{c}$ & $\tau_{\mathrm{em}}{ }^{d}(\mu \mathrm{s})$ \\
\hline \multirow[t]{3}{*}{$T t \mathrm{H}-\mathrm{NOX}$} & 400 (173) & 668 & $1.7 \times 10^{-4}$ & $7.7\left(-\mathrm{O}_{2}\right)$ \\
\hline & $524(10.7)$ & $\sim 734^{b}$ & & $2.9\left(+\mathrm{O}_{2}\right)$ \\
\hline & 555 (13.9) & & & \\
\hline \multirow[t]{3}{*}{$\mathrm{Mb}$} & 397 (197) & 663 & $4.8 \times 10^{-5}$ & $37.3\left(-\mathrm{O}_{2}\right)$ \\
\hline & $518(12.2)$ & $\sim 733^{b}$ & & $12.2\left(+\mathrm{O}_{2}\right)$ \\
\hline & $553(13.2)$ & & & \\
\hline \multicolumn{5}{|c|}{${ }^{a} \lambda_{\mathrm{ex}}=550 \mathrm{~nm}}$. \\
\hline \multicolumn{5}{|l|}{$b$ shoulder. } \\
\hline \multicolumn{5}{|c|}{${ }^{c} \lambda_{\mathrm{ex}}=550 \mathrm{~nm}$, no $\mathrm{O}_{2}$} \\
\hline
\end{tabular}


Table 2

Comparison of $\mathrm{Ru} T t \mathrm{H}-\mathrm{NOX}$ with select $\mathrm{O}_{2}$ sensors

\begin{tabular}{lrccc}
\hline Complex & $\begin{array}{r}\boldsymbol{k}_{\mathbf{q}} \\
\left(\mathbf{m m H g}^{-\mathbf{1}} \mathbf{s}^{-\mathbf{1}}\right.\end{array}$ & $\begin{array}{c}\boldsymbol{\tau}_{\mathbf{0}} \\
(\boldsymbol{\mu s})\end{array}$ & $\begin{array}{c}\text { Precision }^{\boldsymbol{a}} \\
(\mathbf{m m H g})\end{array}$ & Ref. \\
\hline $\mathrm{Ru} \mathrm{Tt}$ H-NOX & 1350 & 7.7 & 5.0 & this work \\
$\mathrm{Ru}^{\mathrm{II}}(\mathrm{bpy})_{3}{ }^{2+}$ & 4300 & 0.58 & 21 & 16 \\
Oxyphor & 293 & 707 & 0.25 & 17 \\
PtP-C343 & 150 & 60 & 5.9 & 12 \\
\hline
\end{tabular}

$a_{\text {Determined assuming an error of } 2.5 \% \text { in } \tau_{0} \text { measurement }}$ 